\title{
The Effectiveness of Anagram Technique in Teaching Vocabulary
}

\author{
Ahdian Rosadi \\ MTs. Al-Majidiyah NW Majidi \\ Email:ahdian16@gmail.com
}

\begin{abstract}
This study aimed at finding out the effectiveness of anagram technique in teaching vocabulary at the seventh grade of MTs. Al-Majidiyah NW Majidi in the school year 2015-2016. This study is a pre-experimental design. The sample was one class consisted of 30 students. The data collection was done by administering pretest and post-test in the form of objective test. In the data analysis, Paired Sample T-Test was used to prove the hypothesis. Based on the data gained, it was found that the mean score of the pre-test was 18.67 while the mean score of the post-test was 25.30. It meant that there was a significant difference in the mean scores

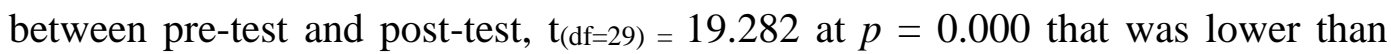
0.05. It means that the alternative hypothesis was accepted which indicates that anagram technique was significantly effective in teaching vocabulary. Additionally, the result of this research shows that anagram is a good vocabulary learning strategy. It encourages greater self-direction for learners. Thus, it is strongly suggested that teachers apply this technique to help improve students' vocabulary.
\end{abstract}

Keywords: anagram, vocabulary

\section{Introduction}

Language is one of tools used to communicate which is more complete and effective to convey idea, message, purpose, feeling, and opinion to other people. It is one of the implementation of language function in society to express mind, feeling, opinion, ideas, etc. Language is also used as connector in teaching learning process. Through language proficiency, students can increase their knowledge, widen their thoughts, and develop their creativities. Basically, 
language is mostly important in daily life because through it people can interact to other people in the whole parts of the world, especially English.

English as one of the language in the world is very important to learn because it can be used in giving or receiving information and for the development of education, technology, and arts. Preparing young learners to study English as early as possible is very crucial because their brain and memory are ready for learning and most of them can learn quite well.

Based on the School Based Curriculum (SBC; well known as KTSP), there are four skills that must be mastered in English subject by the students in order to be able to communicate effectively. The four skills are listening, speaking, reading, and writing. Meanwhile, the four skills have some aspects. One of them is vocabulary.

Vocabulary is the knowledge of words and word meanings. It not only implies a definition but also implies how that fits into the world. In addition, vocabulary is list of words with their meaning especially in a book for learning a foreign language (Oxford, 2008). It refers to the stock of words used by group of people or by a particular person.

Based on four skills of language, election of vocabulary which is taught and examined can be divided into four parts; they are hearing or listening which is also known as passive/conversing, reading or passive/writing, speaking or active/conversing, and writing active/writing (Heaton, 1990).

Vocabulary is one of the elements of language that should be mastered by language learners. To be able to communicate well, vocabulary plays very important roles. The language learners cannot understand what people convey orally or in written if they have difficulties in deciding a word in which as a symbol of ideas is uttered.

Vocabulary is not something that can ever be fully mastered. It is something that expands and deepens over the course of a life time. In reality, it is difficult to be learned. Lack vocabulary is one of the main problems often is faced by students in learning English. According to Ghazal (2007), vocabulary learning is one of the major challenges foreign learners face during the process of learning a language.

By and large, knowledgeable, strategic, adaptive, and reflective teachers may make a difference in students' learning. The roles of both, teacher and students, are important in teaching and learning vocabulary. Any teacher must be able to create fun learning to lead students into a more active instructional process.

However, based on the result of the observation conducted at MTs. AlMajidiyah NW Majidi, the students were not interested in learning English especially vocabulary. They also did not keep their full attention in the their tasks, so that the instructional process did not run well. This situation happened because 
the technique used might not be suitable. The teacher applied non-various technique in teaching learning so the students were bored joining the lesson. Besides, the teacher just wrote some words on the white board then asked students to write on their books. Sometime, the teacher asked the students to memorize the vocabulary in front of the classroom one by one, and it made the students afraid in learning English. Thus, it is important to use a new technique to help students in solving their vocabulary problems.

One of the techniques which can be used is Anagram technique. The broadest definition of an Anagram, according to Collins Cobuild English Dictionary, is "a word or phrase created by re-arranging the letters of another word or phrase, in which every letter in the original is used in the creation of the new phrase." Anagram comes from the Greek "ana," meaning "after" and "gramma," meaning "letter, or writing" (in Saufiyah Zahrah and Albadri, 2015).

According to Collins in Bachtiar (2014), anagram technique is a type of word play, the result of rearranging the letters of a word or phrase to produce a new word or phrase, using all the original letters exactly once. For example, orchestra can be rearranged into carthorse. In addition, there are three main things to do in anagram. The first is letter of a word or phrase must be rearranged, and the second new word or phrase must be created. The third, every letter of the original must be used in the new expression. Each letter can only be used as many times as it appears in the original (If there are 2 B's in the original, then the new expression must have the same number of B's. This process creating new words is obviously good for vocabulary mastery.

By using this technique, the students will not be bored because this technique is appropriate to their characteristics which is they incline more interested to play, meanwhile anagram techique is a type of word play. Many words will be got through this technique. Automatically, this will increase students' vocabulary.

Applying this technique means to help students to raise their curiosity to master more vocabulary. Anagram technique is a technique that can make the students have capability to develop their mastery on vocabulary. Playing more anagram helps increase students vocabulary. In more advance, students are forced to memorize more words, so they can create more words in the anagram. In the memorizing and constructing process, students learn to be patient. It is also to help students to monitor their mastery about how to master vocabulary in short time.

Based on the background of the study, a study was conducted to see the effectiveness of anagram technique in teaching vocabulary at the seventh grade of MTs. Al-Majidiyah NW Majidi in the school year 2015-2016. Thus, two statements of problems are explored here. Those are: 
1. Is anagram technique effective in teaching vocabulary at the seventh grade of MTs. Al-Majidiyah NW Majidi in the school year 2015-2016?

2. How is the effectiveness of anagram technique in teaching vocabulary at the seventh grade of MTs. Al-Majidiyah NW Majidi in the school year 20152016 ?

Based on the statement of the problem above, the purpose of this study was to know whether anagram technique was effective and how effective it was in teaching vocabulary at the seventh grade students of MTs. Al-Majidiyah NW Majidi in the school year 2015-2016.

The result of this study is expected to let teachers know the benefits of anagram for students' foreign language vocabulary development. By this, teachers -especially English teachers - can have some concepts of how to teach and increase their students' vocabulary mastery. For more advance and deeper research, the result of this research is also expected to be a reference for those who are interested to conduct further investigation.

\section{Method}

\subsection{Participants}

The participants of this study were all of the seventh grade students of MTs. Al-Majidiyah NW Majidi in the school year 2015-2016 which consisted of 2 classes. The number of the population of this study was 59 students. Purposive random sampling was applied to take sample from the two classes; they were VIIA and VIIB. As the result, VIIA was chosen as the experimental group.

\subsection{Procedure}

\subsubsection{Preparation for treatment}

According to Barus in Bachtiar (2014), there are many ways in applying anagram to the students after the teacher explaining the material, such as:

a. Asking the students to form other words from the key word given;

b. Asking the students to rearrange the letters in bracket after that fill in each blank with the appropriate anagram to complete the sentence;

c. Asking the students to omit one or some letters of the key word and transpose the rest;

d. Asking the students to transpose the letters of the word and form another word by using those letters exactly once based on the definition;

e. Asking the students to match the scramble word on the left to its arrangement on the right.

In this research, the treatment encompasses some main steps. The framework in applying anagram technique is shown in Figure 01. 


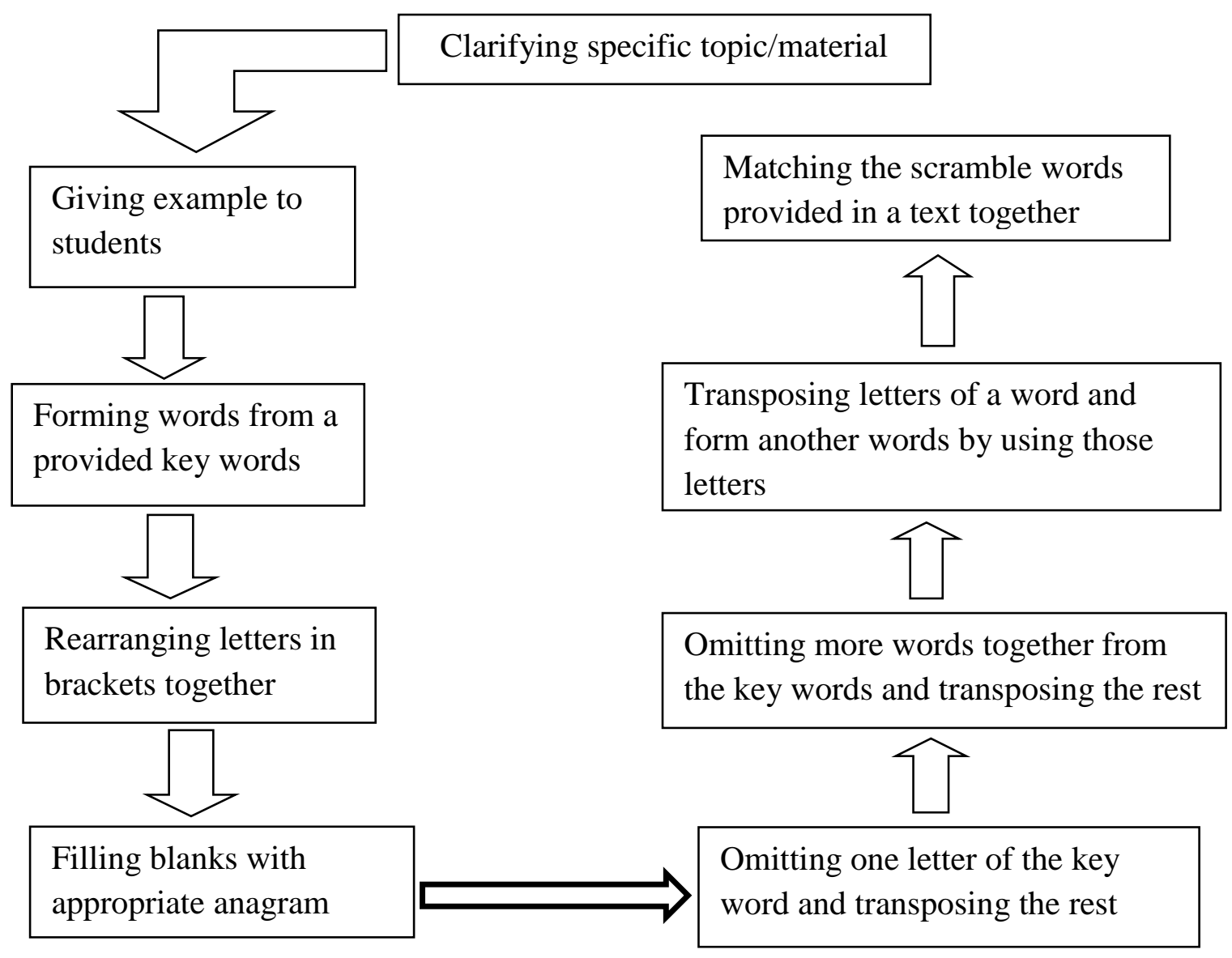

Figure 1. Framework of Applying Reciprocal Peer Tutoring

\subsubsection{Data Collection}

In this research, pre experimental research in one group pre-test and posttest design is applied because this research had no control of extraneous variable. This research does not have random of subjects to groups. The one-group pre-test and post-test design usually involves three steps: (1) administering a pretest to measure a variable; (2) applying the experimental treatment $X$ to the subjects; and (3) administering a posttest, again measuring the variable. Differences attributed to application of the experimental treatment are then evaluated by comparing the pretest and posttest scores (Ary et al, 2010, p.303). It is shown in Table 01.

Table 01

Research Design: One-Group Pretest-Posttest Design

\begin{tabular}{lll}
\hline Pretest & Investigated Variable & Posttest \\
\hline$Y_{1}$ & $\mathrm{X}$ & $\mathrm{Y}_{2}$ \\
& & \\
\hline
\end{tabular}

Notes:

$\mathrm{Y}_{1} \quad$ : Pre-test 


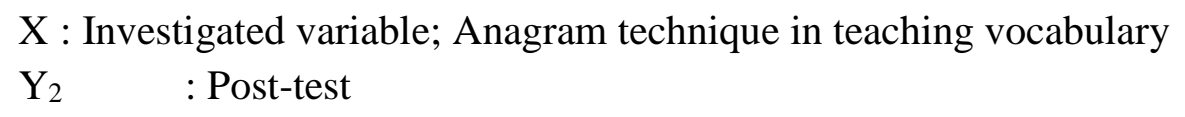

(Ary, et al, 2010)

This research consists of an investigated variable. The investigated variable of this research is vocabulary through anagram technique. The instrument used in this study is a test. The test is in form of multiple choice and matching meaning to measure students' vocabulary mastery. In this test, 30 items are provided: 25 items of multiple choices and 5 item of matching meaning. Every correct answer is given 1 score and each wrong answer is given 0 score.

In collecting data, a pre-test and post-test were administered. The pre-test was administered before doing the treatment, and the post-test was after doing the treatment through anagram technique. This aimed at knowing the students' governance on vocabulary after applying Anagram technique.

\subsubsection{Data Analysis}

The technique of analyzing the data in this research was descriptive statistics. This technique was used to find out the highest and lowest score, mean score and standard deviation of students' test achievement. The present researcher calculated the Mean Score and Standard Deviation of the experimental group by using SPSS 17 for Windows (Moedjito, 2014). In testing hypothesis, the collected data should be normal and homogeneous. If the values of the significance value level of the investigated variables are higher than .05 , the distribution of the data are normal and homogeneous (Moedjito, 2014).

The research hypothesis was formulated into Anagram technique was significantly effective in teaching vocabulary at the seventh grade of MTs. AlMajidiyah NW Majidi in the school year 2015-2016. This hypothesis then was tested by using Paired-Sample t-test (SPSS 17.0 for windows). If the significance (2-tailed) value level of the analyzed data is lower than .05, the alternative hypothesis of this study is accepted and null hypothesis of this study is rejected.

\section{Results}

Referring to the data gained, the standard deviation of the pre-test was 2.279 , and the standard deviation of the post-test was 1.179. Meanwhile, the mean scores in the pre-test and post-test were 18.67 and 25.30. The mean score after the technique was implemented was higer than the mean score before the treatment was implemented. It means that anagram technique was effective in teaching vocabulary. The scores are summarized in Table 02. 
Table 02

Summary of Frequency Statistics

\begin{tabular}{|c|c|c|c|}
\hline & & Pretest & Posttest \\
\hline \multirow[t]{2}{*}{$\mathrm{N}$} & Valid & 30 & 30 \\
\hline & Missing & 0 & 0 \\
\hline \multicolumn{2}{|c|}{ Mean } & 18.67 & 25.30 \\
\hline \multicolumn{2}{|c|}{ Median } & 18.50 & 25.00 \\
\hline \multicolumn{2}{|c|}{ Mode } & $18^{\mathrm{a}}$ & 25 \\
\hline \multicolumn{2}{|c|}{ Std. Deviation } & 2.279 & 1.179 \\
\hline \multicolumn{2}{|c|}{ Minimum } & 14 & 23 \\
\hline \multicolumn{2}{|c|}{ Maximum } & 25 & 28 \\
\hline \multicolumn{2}{|c|}{ Sum } & 560 & 759 \\
\hline
\end{tabular}

Furthermore, normality test is used to check whether the data distribution in the pre-test and post-test was normal or not. Moreover, the data are normal if the value of the significance level of the investigated variable is higher than 0.05. Based on the data gained from One-Sample K-S, the value of the Asymp. Sig. (2tailed) on the pre-test and post-test was higher than 0.05. It implied that the data distribution was normal. This result is shown in Table 03.

Table 03

Summary of Normality through

One-Sample Kolmogorov-Smirnov Test

\begin{tabular}{llrr}
\hline & & Pre-test & Post-test \\
\hline $\mathrm{N}$ & & 30 & 30 \\
Normal Parameters ${ }^{\mathrm{a}, \mathrm{b}}$ & Mean & 18.67 & 25.30 \\
& Std. Deviation & 2.279 & 1.179 \\
Most Extreme & Absolute & .120 & .234 \\
Differences & Positive & .120 & .234 \\
& Negative & -.087 & -.200 \\
\hline Kolmogorov-Smirnov Z & .655 & 1.280 \\
Asymp. Sig. (2-tailed) & & .784 & .075 \\
\hline
\end{tabular}

Moreover, homogeneity testing was conducted to know whether the data were homogenous or not. The data are homogenous if the values of the level significant is greater than $p=0.05$. Here, the value of Levene's test $=9.950$ at $p=$ 
0.003 which was greater than $p=0.05$. It means that the data were homogeneous. The homogeneity score is shown in Table 04.

Table 04

Homogeneity of Variances

\begin{tabular}{cccc}
\hline \multicolumn{4}{c}{ Score } \\
\hline $\begin{array}{c}\text { Levene } \\
\text { Statistic }\end{array}$ & df1 & df2 & Sig. \\
\hline 9.950 & 1 & 58 & .003 \\
\hline
\end{tabular}

A hypothesis testing was conducted to know whether the hypothesis was accepted or rejected. The present researcher used paired-sample t-test to analyze whether there was a significant difference in the mean score between the pre-test and the post-test. The present researcher determined the confidence interval of the difference which was $95 \%$ and the standard significance (2-tailed) value level was 0.05. If the significance (2-tailed) value level of the analyzed data is lower than 0.05 , it means the alternative hypothesis $(\mathrm{Ha})$ is accepted and the null hypothesis (Ho) is rejected. If it is higher than 0.05 , the alternative hypothesis (Ha) is rejected and the null hypothesis (Ho) is accepted. The result of the paired sample test is shown in Table 05.

Table 05

Paired Samples Test

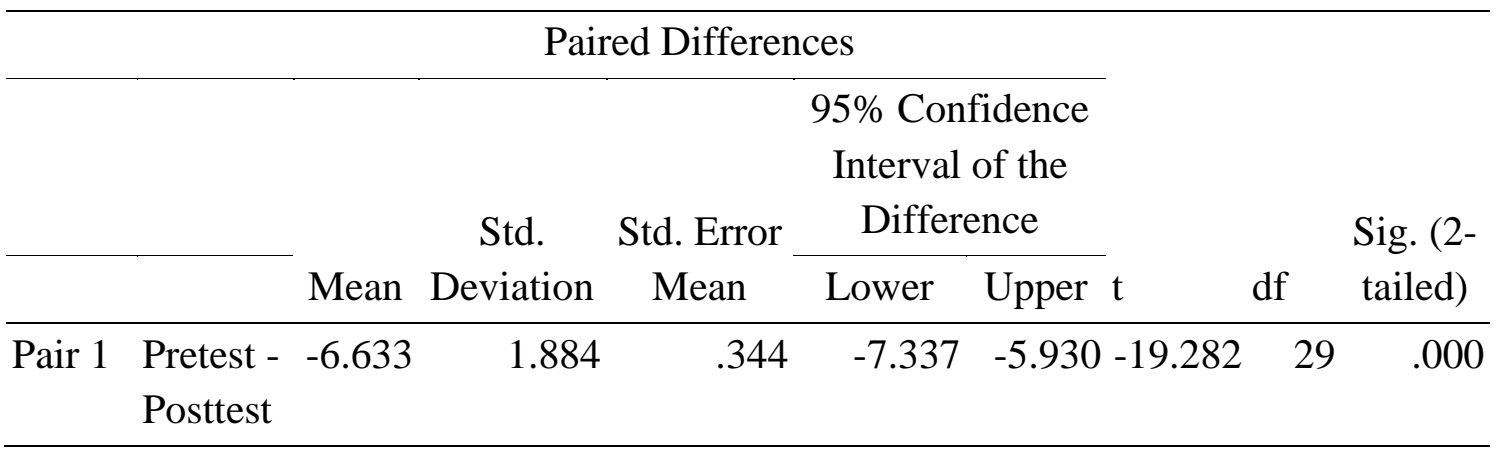

Based on the data gained, the value of sig (2-tailed)- $t$ was 0.000 at $t$-test value 19.282; it means that the value of sig (2-tailed) $t$ was 0.000 lower than 0.05 , so the alternative hypothesis (Ha) was accepted and the null hypothesis (Ho) was rejected. Therefore, it is concluded that anagram technique was significantly effective in teaching vocabulary for the seventh graders of MTs. Al-Majidiyah NW Majidi in the school year 2015-2016. 


\section{Discussion}

Vocabulary is an important ingredient of language, and vocabulary learning is an essential part of foreign language learning. Language learners need a wide array of words in a target language to be able to tackle both production and comprehension activities successfully in the foreign language. One way to help learners is by equipping them with variety of vocabulary learning strategies.

In line with Brown (1988), the finding in this research shows the advantages of anagram: increasing students' English vocabulary, helping students to strengthen their memory, training students to be patient in learning anagram, and training students to control their emotion. This theory is proven by the finding of the research.

Additionally, some previous research show that anagram is effective in teaching and learning vocabulary. The findings of the previous research are similar to the findings in this research which is that anagram is effective in helping students to master more vocabulary. For an instance, Saufiyah Zahrah and Albadri (2015) found that random anagram was able to improve the year 5 pupils' spelling, motivation to learn vocabulary, and mental retention in spelling. In short, in this present research, the significant difference of the students' score in the pretest and posttest shows positive changes in the students' vocabulary mastery through anagram.

\section{Conclusion}

Based on the data analysis and the discussion, it was found out that the t-test was higher than the t-table $(19.282>2.045)$. This indicated that the null hypothesis $\left(\mathrm{H}_{0}\right)$ was rejected and the alternative hypothesis $(\mathrm{Ha})$ was accepted. In short, anagram technique was effective in teaching vocabulary improving the students' vocabulary mastery of the seventh grade of MTs. Al-Majidiyah NW Majidi in the school year 2015-2016. Thus, foreign language teachers should consider this technique as an alternative technique in teaching English.

The result of this research shows that anagram is a good vocabulary learning strategy. It encourages greater self-direction for learners. Through anagram, students lead their self to a harder work finding words from the provided alphabets. They consult the teacher and dictionary, and they are even more active having discussion with their mates. Besides improving students' vocabulary mastery, it also creates fun learning for students. Thus, it is strongly suggested that teachers apply this technique to help improve students' vocabulary. 


\section{References}

Anagram. (2005). Retrieved from http://www.inneryou.info/anagrams.htm.

Brown, Hugh and Brown, Margaret. (1988). Word Play. Penrith, Cumbria: Reed's Ltd.

Ghazal, Lotfi. (2007). Learning Vocabulary in EFL Contexts through Vocabulary Learning Strategies. Novitas Royal; Research on Youth and Language. Vol.: 1(2), pp.84-91.

Heaton, J.B. (1990). Classroom Teaching. New York: Longman.

Maimunah Bachtiar. (2014). Improving students" vocabulary achievement in reading recount text through anagram technique. Retrieved from e-Journal of UNIMED.

Moedjito. 2014. Basic statistic for research in language education. Unpublished Modul: STKIP Hamzanwadi Selong, Nusa Tenggara Barat, Indonesia.

Saufiyah Zahrah and Albadri. (2015). Improving Year 5 Cerdas Pupils' Spelling through Random Anagram. IPG Kampus Dato' Razali Ismail; Department of Languages. 